\title{
The Society That Almost Wasn't: Issues of Professional Identity and the Creation of The American Phytopathological Society in 1908
}

\author{
Paul D. Peterson and Karen-Beth G. Scholthof
}

First author: Department of Entomology, Soils, and Plant Sciences, Pee Dee Research \& Education Center, 2200 Pocket Road, Clemson University, Florence, SC 29506-9706; and second author: Department of Plant Pathology and Microbiology, 2132 TAMU, Texas A\&M University, College Station 77845-2132. Accepted for publication 8 September 2009.

\begin{abstract}
Peterson, P. D., and Scholthof, K.-B. G. 2010. The society that almost wasn't: Issues of professional identity and the creation of The American Phytopathological Society in 1908. Phytopathology 100:14-20.

The creation of The American Phytopathological Society (APS) in 1908 was a response to the developing professionalism in the biological and agricultural sciences in the United States between 1880 and 1920. During this period, a new generation of plant pathologists emerged in the United States Department of Agriculture, agricultural colleges, and state

agricultural experiment stations with a methodological and theoretical framework to determine the cause and nature of disease and make control recommendations based on experimental evidence. These plant pathologists, in turn, became eager to establish a professional identity, for some an identity separate from traditional botany and mycology. For these scientists, the goal would be facilitated by establishing a new society for plant pathologists. The story of the creation of APS is best understood within the nature of the ensuing debates over identity and the merits of forming a new society among its first generation of scientists.
\end{abstract}

Looking back over a century of success for The American Phytopathological Society (APS), it is tempting to presume that its formation may have been a fairly easy, straight-forward event. Yet, in 1908 plant pathologists probably would not have judged the success of APS as a foregone conclusion. Interestingly, the creation of the Society was actually an uphill battle among scientists with a good bit of uncertainty over whether or not to form a separate society dedicated to plant pathology.

This contentious beginning provides an interesting story of our Society's roots, while also offering a deeper appreciation of what it means to be a plant pathologist. Our intent here is to briefly summarize the nature of the debate surrounding the establishment of our Society and to provide the key events that allowed the creation of APS. We hope to show that in many ways the creation was a consequence of the successes in the science of plant pathology in the early 20th century, as well as the visionary leadership of several influential scientists at the U.S. Department of Agriculture (USDA), state agricultural experiment stations, and land grant colleges. However, more than any other factor, the creation of APS resulted from a professional identity crisis from plant pathologists motivated to establish a professional identity separate from traditional fields of botany and mycology. Even today, plant pathology is a discipline that straddles multiple fields in the

Corresponding author: K.-B. G. Scholthof; E-mail address: kbgs@tamu.edu

This paper is modified from presentations made in August 2008 at the Centennial Meeting of The American Phytopathological Society, Minneapolis, Minnesota, and the IXth International Congress of Plant Pathology, Turin, Italy. P. Peterson is APS Historian and served on the Centennial Planning Committee for the APS Centennial in 2008 .

* The $\boldsymbol{e}$-Xtra logo stands for "electronic extra" and indicates that the online version contains a program of the first annual meeting of the The American Phytopathological Society.

doi:10.1094/PHYTO-100-1-0014

(C) 2010 The American Phytopathological Society sciences, and we still grapple with issues of identity both within and outside of the Society. The scientists who pushed for the creation of the Society had a clear perception of their identification as plant pathologists, as opposed to botanists, mycologists, or other scientists, and these plant pathologists had a firm conviction that the science of plant pathology could advance basic scientific knowledge while also being practical.

\section{PLANT PATHOLOGY CIRCA 1908}

When APS was created in 1908, plant pathology in the United States was only about three decades old, but much had happened in those decades. Scientists interested in plant diseases during this era found themselves working with better microscopes and using new techniques for cell staining, tissue sectioning, and preparing pure cultures of bacteria and fungi. They also were part of a new emphasis on plant morphology and physiology instead of the earlier focus on taxonomic classification. This scientific wave of "new botany" brought plants into the laboratory as experimental material, contributing to modern concepts of cell theory and the germ theory of disease $(6,16)$. Along the way, the study of plant diseases was radically transformed from an earlier era of systematic mycology - that had been performed by amateur naturalists and botanists who spent their time leisurely cataloging fungi and diseases-to a new period of the specialist. This new generation of scientists took on the job of determining the cause and nature of disease and making control recommendations based on experimental precision.

By 1908, plant pathologists in the United States had developed new areas of study and were no longer limited by their mycological training. American scientists had founded the field of plant bacteriology and were beginning to investigate diseases caused by viruses and nematodes. By 1908, plant pathologists in the United States were able to accurately diagnose and predictably control several diseases. Through the research by scientists at the USDA and the state agricultural experiment stations, fungicides emerged as an important weapon in the plant pathologists' arsenal against 
plant-pathogenic fungi in agricultural practice. Beverly $\mathrm{T}$. Galloway, the scientist and administrator in charge of all plant pathology at the USDA in this era, claimed that it "was during this period that some of the most troublesome and destructive pests of our fruit, vegetable and farm crops were mastered and the spraying of farm crops became as much a part of good husbandry as plowing, fertilizing, cultivating and similar practices" (9). In the early 20th century, in addition to fungicides, U.S. plant pathologists were also making progress in identifying and utilizing plants with resistance to diseases of economic importance, although genetics and plant breeding were still in their infancy.

Around the time that momentum was gathering to form APS, plant pathologists in the United States worked in one of several unique American institutions of agricultural education and research: land grant colleges, state agricultural experiment stations, or the USDA. These institutions were created to support and encourage the rapid development of American agriculture through the practical application of agricultural science. These institutions became venues for specialization within the applied sciences. This included the new field of plant pathology that had several highly visible triumphs in determining causes of disease and developing methods for their management $(6,10,18-20)$.

Even with these successes and unique institutional support, plant pathology in the United States faced a major identity problem at the turn of the century. Plant pathologists in the United States wanted to be considered specialists but had not managed to distance themselves professionally from botanists. Scientists are, after all, defined by where they assemble as a group and where they publish their research. These plant pathologists only met with botanists in botanical organizations and, other than European plant pathology journals, they could only publish in botanical journals in the United States.

\section{PRE-APS ORGANIZATION OF PLANT PATHOLOGISTS}

Prior to the creation of APS, the American Association for the Advancement of Science (AAAS) was the primary scientific society in the United States for those working on plant diseases. Mycological papers had appeared on the AAAS program nearly from its beginning in 1848, but attention to plant diseases began around 1880, reflective of new developments in diagnosing and controlling diseases (6). Around the same time, also reflective of the new botany and the increased specialization of the plant sciences generally, the AAAS began to find itself increasingly divided internally along disciplinary lines. As a result, the AAAS began to be divided into sections and subdivisions. It was the pressure produced by this specialization and the subsequent efforts to find a place to fit the new specialized fields like plant pathology, both within and outside of this parent organization, that is relevant to our story $(2,4)$.

With regard to the creation of the sections in AAAS, the first of these involving plant disease research was in Section B: natural history, which was created in 1875. In 1882, AAAS established Section F, which was dedicated to biology, and reflected the continued growth and specialization in the biological sciences. However, this section did not include borderline fields of biology such as microscopy, histology, and anthropology. A number of prominent people who played pivotal roles in the early development of plant pathology in the United States were members of Section F (6). In 1893, the AAAS established Section G, dedicated to botany, in part as a response to the developments in "New Botany." Among the 34 papers read in Section G in 1893, six dealt with plant diseases (1).

While the AAAS was splitting into formal sections, other efforts to organize America's plant scientists were ongoing and these were consistent with the general movement towards specialization. For example, the American Botanical Club was created during the 1883 AAAS meeting. This was not a formal organization or society-there was no established constitution or a set of bylaws. It was simply an informal gathering from within the AAAS. However, it did represent the growing number of botanical researchers and an increasing need for opportunities for communication among them, including the regular presentation of papers on mycology and plant diseases. The club was active for more than 20 years; the last meeting was held in Philadelphia in 1904.

The Botanical Society of America (BSA) was created during the 1894 AAAS meeting. It was the first major society of botanical scientists in the United States. The intent was to create a more formal society than the American Botanical Club. Membership was restricted to older and better known botanists who were active research scientists and who had published outstanding work $(21,32)$.

In 1897, the American Society for Plant Morphology and Physiology was created with membership qualifications less restrictive than the BSA. Membership was open to most scientists actively engaged in botanical research, a requirement met by demonstration of satisfactory evidence of original research or published papers. The first president was a plant pathologist, William Farlow $(7,31)$. In continuing the trend for the professionalization of science, the American Mycological Society was created in 1903, with membership qualifications less restrictive than the BSA. Not surprisingly, this specialized society included many plant pathologists (7).

Although the enthusiasm for division was thriving among the botanical scientists, such as the sectional splitting within the AAAS and the creation of new organizations, there also was consolidation during the first decade of the 20th century. There was a certain sentiment among scientists (especially the older, traditional botanists) in the BSA, the Society for Plant Morphology and Physiology, and the American Mycological Society that the interests of the botanical sciences as a whole could be best advanced by a single organization. This sentiment was strong enough that, in 1906, a new constitution for a unified organization was adopted and the three organizations became one under the name, the Botanical Society of America (BSA). George F. Atkinson, who had been a member in all three of the uniting organizations, became the first president of this new 119-member society $(7,22,32)$.

Although the older botanists had managed to bring about a single organization in 1906, consolidation did not end the movement to specialize. Nor did it satisfy the younger, applied scientists like plant pathologists, who perceived that "the applied branches of botany" were "being essentially ignored" (7). What it did do was widen a developing divide between the old botanists and the new specialized plant scientists. The new generation saw the consolidation as a step backwards-supporting general botany rather than the rapidly developing applied areas like plant pathology. They also continued to resent the restrictive nature of membership that favored older botanists over the younger applied scientists. As a direct result, many plant pathologists simply refused to apply for membership to the BSA.

\section{THE CREATION OF APS}

The original idea for creating APS likely came from within the USDA. This was not surprising given the power and influence of plant pathology at the USDA in 1908. This was where most of the research was conducted, where the largest single contingent of plant pathologists worked, and where the science had most effectively demonstrated its usefulness to American agriculture through both diagnosing disease and recommending controls. Also, plant pathologists at the USDA in 1908, because of these successes, likely had the strongest sense of a professional identity (6). 
The first idea for a separate society may well have come from Senior USDA Plant Pathologist Cornelius L. Shear. Shear had earned an excellent reputation at the USDA from his initial studies on cotton root rot disease and diseases of cranberry. Shear would be a driving force for the creation of APS, guiding the nascent society in the early years, where numerous hurdles would have to be overcome in order to establish a scientific organization. (A decade later, in 1919, Shear served as the 11th APS President.) During the summer of 1908 , Shear presented the idea for APS to colleagues at the USDA. Then, in November of that year, Shear wrote to state experiment station plant pathologists to get their opinions on organizing a society (18). On 15 December 1908, Shear arranged a meeting of USDA plant pathologists to discuss the matter more formally (Fig. 1). The invitation states that the purpose of this meeting was "to take preliminary steps for the organization of a general society of Plant Pathologists" (23).

At this December 15th meeting, 23 USDA plant pathologists met to discuss forming a new society of plant pathologists. One of the major topics involved lingering bitterness over the restrictive nature of membership in the newly consolidated BSA. Erwin F. Smith wanted to know how membership would be handled in this new plant pathology organization. Those present decided that the proposed society "should be very broad in its scope and should admit to membership all persons engaged in phytopathological work" (6).

As a result of this meeting, C. L. Shear, Donald Reddick (who was at the USDA before going on to an important career at Cornell), and William A. Orton were appointed as a committee to contact plant pathologists across the United States about the idea for the organization of a society $(17,18)$. The committee wasted no time in sending a letter to 130 plant pathologists across the country-it was dated 16 December (Fig. 2). In the letter, the committee relayed the results of the December 15th meeting and invited the plant pathologists to a formal gathering at the upcoming AAAS meeting, taking place 2 weeks later, on December 30th in Baltimore, Maryland. The committee's intent was that these plant pathologists would "take part in the organization of the proposed society which, it is believed, can exercise great influence in advancing the study of phytopathology in America" (30).

The responses to the invitation letter fell into two categories. There were strong supporters like H. H. Whetzel of Cornell who responded that the scheme met with his "hearty approval" and he hoped to soon see "the final completion of such an organization" (35). L. R. Jones of the Vermont Agricultural Experiment Station (where he worked prior to going to the University of Wisconsin) confirmed that he would attend the meeting on December 30th, and also approved of the movement toward the organization of a society of plant pathologists (11).

But there were also dissenters. George F. Atkinson, also of Cornell, was cold to the idea of forming a new society and responded that, even if one were formed, he would not join anyway, citing commitments to other scientific societies. It must be remembered that Atkinson, unlike Whetzel and Jones, was much more of a botanist with a side interest in plant diseases, rather than a true plant pathologist. He also had been a key figure in the consolidation movement that established the new BSA back in 1906 (3).

In conjunction with the annual meeting of the AAAS, 54 plant pathologists attended a meeting to discuss the formation of a phytopathological society during the late afternoon of 30 December 1908 at Eastern High School in Baltimore. The organizing committee of Shear, Reddick, and Orton began the meeting with the following statement: "It is our opinion that an American Phytopathological Society, placed upon a broad and generous foundation, may be of invaluable aid in promoting the future development of this important and rapidly growing subject in America, and that its influence may be made of international importance" (29).
The report given by the organizing committee apparently stimulated what was later described as "stormy discussions" between those in favor of a new society and those opposed (33). Those against, like G. F. Atkinson and J. C. Arthur (another scientist with strong professional attachments to botany), argued that such a move would be detrimental to the advancement of botanical unity and organization $(8,26)$. J. C. Walker would later remark that the "Society was formed not without some hard feeling of some prominent mycologists who tried their best" to keep plant pathology "under their wing" (34). Proponents of the new society, on the other hand, insisted that the professional goals of plant pathology could not be attained in the absence of a separate society (29). After a lively discussion, the committee's recommendation to create a society was put to a full vote. It passed by a margin of 32 to 12, again demonstrating that there was considerable objection to forming this new society.

Nevertheless, once the vote had been cast, discussions took place on issues of the time and place of an annual meeting and whether the society should undertake the publication of a journal. The meeting ended with the election of a Council consisting of:

President - L. R. Jones (University of Vermont)

Vice-President - A. D. Selby (Ohio State University)

Secretary-Treasurer - C. L. Shear (USDA)

Councilman - J. B. S. Norton (University of Maryland)

Councilman - B. M. Duggar (Cornell University)

At this point, it might appear that all was settled-the 54 attendees of the 1908 Baltimore meeting had voted to form a new society and had elected a council. Indeed, L. R. Jones, the new President, left Baltimore believing that the issue had been resolved. But, in fact, the case was not closed-doubts remained about creating a new society for plant pathologists and breaking up the new unified BSA. After Jones left Baltimore, ideas began to circulate that there might be ways for plant pathologists to remain with existing organizations, perhaps as a subsection of Section G (botany) of the AAAS (26). Perhaps the creation of APS was not so settled after all.

L. R. Jones and other members of APS Council even appeared to have been amenable to forming a subsection, provided they were permitted to arrange a separate program at the AAAS meeting and were free to publish a journal of phytopathology. Shear, Selby, and Norton wrote that it might be possible to make some arrangement with Section G (botany). This would meet practically "all our requirements, and at the same time avoid some of the opposition which has been made to our undertaking" (13). There also was significant interest by the BSA in having APS come into the fold. However, it was decided that Phytopathology, a specialist journal, was the most pressing need, and APS declined the merger and proceeded to form an independent society. It should also be noted that APS continued to meet in conjunction with Section G (botany) of AAAS until $1941(15,17)$.

With these ideas in the background, the first Council meeting of the proposed APS took place in Washington, D.C., on March 2627, 1909. At this meeting, Council considered the possibility of becoming a subsection of AAAS Section G. Council proposed to hold their first regular annual meeting of plant pathologists from December 28-31 at the next AAAS meeting in Boston. Council also recommended plans for the publication of a journal, perhaps through the USDA (29).

By March 1909, it appeared that perhaps the plan for a separate society would fall by the wayside and American plant pathologists would align themselves with a subsection of AAAS Section G. But then, a couple of important events occurred that completely changed the course of thinking about creating a new society. First, in April 1909, AAAS Council directed sectional secretaries to arrange a program for each section of no more than two sessions and to only accept papers of a general botanical nature. Obviously, this was a problem for plant pathologists planning their own multi-day meeting in December and planning 
to submit specialized research papers. C. L. Shear (USDA) wrote to L. R. Jones that the new AAAS policy held "little advantage... to us in our carrying out the proposed arrangements to become a sub-section of Section G" (25).

Then, in May, William Beal (Michigan), the secretary of the AAAS sectional committee for Section G, wrote a very negative letter to L. R. Jones about plant pathologists even remaining with AAAS. Beal, another one of the older botanists, told Jones that "The AAAS had all the sections it could take care of. Separate societies, in the opinion of the sectional committee, had already multiplied to an unprofitable degree" (5). From this, Beal suggested to Jones that plant pathologists form a liaison with the Society for the Promotion of Agriculture (SPA) or the BSA.

The events of April and May 1909 seem to have been the turning point in whether to create a new society or not. There was now little or no chance that plant pathologists would unite with the BSA, and the idea of a viable link with the SPA had already

\section{UNITED STATES DEPARTMENT OF AGRICULTURE, BUREAU OF PLANT INDUSTRY.}

INVESTICATIONS OF DISEABES OF FRUITS.

Washington, D. C., December 15, 1908.

All workers in Plant Pathology are invited to meet at 4 P.M. today in

room 314 to take preliminary steps for the organization of a general society

of Plant Pathologists.

Dr. E. F. Smith 4 \& $D$.

- Mr. J.R. Johnson, m Leave

Miss Florence Hedges, F.H.

Miss MoCullogkh, Lim,

Dr. Haven Metcale, $H$ y

Dr. G. G. Hedgecock, M. 4 .

- Dr. P. Spaulding, on Sepone

Mr. w. A. Orton, onged

Mr. W. w. Gilbert, Wyrs.

- Mr. Harter. Inve fort

Miss A. Ames, A,A.

Mrs. Patterson, Have'1. goto denlults.

Miss Charles, T.Jel.

- Mr.M. B. Waito, m Leane

Mrs. A. K. Wood. alwer,
Mr. James B. Roror, YPR.

Mr. T. W. Ayres, $\sigma, \mathcal{W}, a_{\text {. }}$

Mr. L. A. Hawkins, S leth.

Mr. Geo. F. Miles, offrm.

Mr. W. M. Scott,

Miss C. Hasse, h. X. X.

Mr. F. v. Rand, 7., R. L cave of $2: 45^{\circ}$

Mr. M. A. Carleton, WNe

Mr. Johnson, 6.6.

Mr. C. 0. Townsend, $C \circ T$

Mr. E. C. Rittue,

Mr. H. B. Shaw, on

Miss Brown, $\quad$ A.A.B,

Miss Jameson, C.O.g.

Mr. Reddick. S,R.

Fig. 1. Memorandum from C. L. Shear to USDA plant pathologists calling for a meeting to discuss the organization of The American Phytopathological Society. The meeting was held at the USDA Building, Washington, D.C., on December 15, 1908. The image is used with permission of the Department of Special Collections, The Parks Library, Iowa State University, Ames. 
Washington, D. C., December 16, 1908.

\section{At a meeting of plant pathologists held at Washington,} D. C., December 15, 1908, and after consultation with several experiment station pathologists, it was unanimously decided that an effort should be made to organize an American pathological society. The undersigned were appointed a committee to arrange for a preliminary meeting in connection with the Amer1can Association for the Advancement of Science at Baltimore. You are cordially invited to be present December 30, 1908, at an hour and place to be announced later and take part In the organization of the proposed society which, it is believed, can exercise great influence in advancing the study of phytopathology in America. If impossible for you to be present, w11l you kindly inform the committee whether you would be willing to join such a society and also what you think should be its policy with regard to time and place of meetings.

\section{I. Shear.}

\section{Committee: Donald Reddick.}

\section{T. A. Orton.}

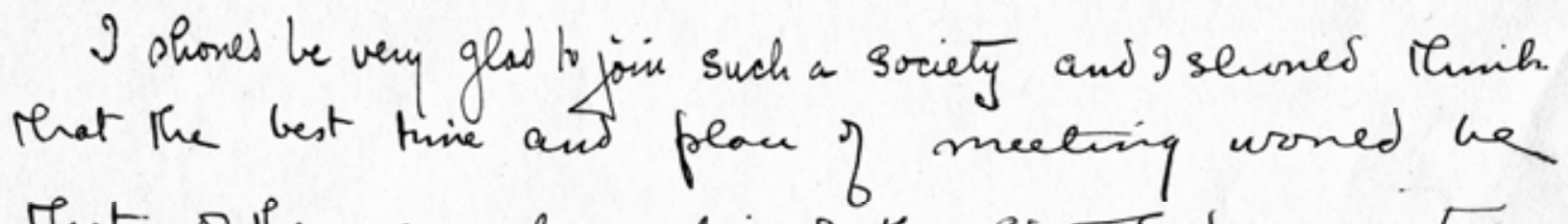
That of the annual meting of the state $E_{x}$ perment Station workes. 


\section{American Phytopathological Society}

WASHINGTON. D. C.

October 25, 1909.

Prof. Goo. F. Atkinson,

Ithaca, N. $\mathrm{y}$.

Dear Sir:

I am instructed by the Council of the American Phytopathological Society

to invite you to become a charter member of the Society. Please signify your acceptance of the invitation by remitting to the Secretary-Treasurer fifty cents by Post-office money order, to be used in defraying the expenses of the Society this year. Please also give titles of such papers as you wish to present at the coting meeting.

Arrangements are being made to hold the first meeting of the Society in connection with the American Association for the Advancement of Science at Boston, Vass, during Convocation Jeok, December 27, 1909, to January 1, 1910, at which time questions relating to the future policy of the Society and its relations to Section $G$ of the A.A.A.S., will be definitely determined.

Te hope to have a good programme, a large attendance and a very profitable meeting. The programe will be prepared as soon as possible.

Please do not fail to send titles of papers and abstracts of the same, though the latter may be forwarded later if more convenient.

Yours very truly,

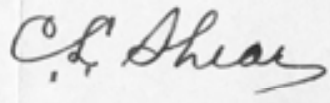

Secretary-Treasurer.

Fig. 3. A letter of invitation to become a charter member of The American Phytopathological Society (APS) and attend the first annual meeting in Boston, Massachusetts, in December 1909. This letter was written by C. L. Shear, APS President to George F. Atkinson on October 9, 1909. Shear sent letters to 130 plant pathologists, botanists, and mycologists in the United States. (Courtesy of the Division of Rare \& Manuscript Collections, Carl A. Kroch Library, Cornell University, Ithaca, NY.) 
been considered and rejected (14). Perhaps we have W. J. Beal to thank for solidifying L. R. Jones' opinion on creating APS. After the letter from Beal, Jones consulted with Council members and decided that plant pathologists would form a separate society. Jones insisted that the best strategy forward was for plant pathologists to put together the strongest possible program at the upcoming Boston AAAS meeting. A program, that in Jones' words, would "command respect and attention" (12). With the decision made to form a new society and to hold the first regular APS meeting in conjunction with the upcoming AAAS annual meeting in December, the APS Council sent a letter of invitation to plant pathologists to become charter members (Fig. 3). Membership dues were set at 50 cents, and the invitation also served as a call for papers (24).

For 2 days, 30 to 31 December 1909, under the leadership of President L. R. Jones of the University of Wisconsin, 50 members assembled for the first annual meeting of The American Phytopathological Society. The meeting was held at the Harvard Medical School in Boston, Massachusetts, in affiliation with the AAAS annual meeting (e-Xtra). The program involved three sessions during those 2 days, and presentations included 45 scientific papers authored by 38 men and 3 women from 15 states (California, Delaware, Louisiana, Maine, Michigan, North Carolina, North Dakota, New York, Ohio, Oregon, Pennsylvania, Tennessee, Virginia, Vermont, and Wisconsin), Washington, D.C., and Ottawa, Canada. Topics ranged from diseases of fruit, fiber, forage, field crops, and forest trees caused by fungi and bacteria; malnutrition of vegetables; and fungicides. Members heard about results of a wide diversity of recent research on diseases, including potato canker, late blight and blackleg; apple scab; chestnut bark disease; white pine blister rust; sugar beet curly top; peach yellows; and banana blight in the United States, Canada, Cuba, and Central America $(27,28)$.

One previous skeptic later wrote, "the large membership list, the numerous papers presented, and the great enthusiasm... had thoroughly convinced them that the organization of the Society was fully justified" (17). By all accounts, the meeting was "regarded as a great success" (27).

\section{ACKNOWLEDGMENTS}

This work was made possible by funding from The American Phytopathological Society to P. D. Peterson and an NSF Science, Technology, and Society Grant (no. 0724650) awarded to K.-B. G. Scholthof. We appreciate the assistance of archivists at Iowa State University (Park Library), Cornell University (Division of Rare \& Manuscript Collections, Kroch Library), and the National Archives. We also are indebted to C. Griffith, W. Kimler, and H. Scholthof for their helpful comments and suggestions on drafts of the presentations and the manuscript.

\section{LITERATURE CITED}

1. Anonymous. 1893. Proceedings of Section G, A.A.A.S., Madison meeting. Bot. Gaz. 18:333-342.

2. Appel, T. A. 1988. Organizing biology: The American Society of Naturalists and Its "Affiliated Societies," 1883-1923. Pages 87-120 in: The American Development of Biology. R. Rainger, K. R. Benson, and J. Maienschein, eds. University of Pennsylvania Press, Philadelphia.

3. Atkinson, G. F. 1908. Letter to C. L. Shear. George F. Atkinson Papers, 1880-1918. Division of Rare \& Manuscript Collections, Carl A. Kroch Library, Cornell University, Ithaca, NY.

4. Bates, R. S. 1965. Scientific Societies in the United States. MIT Press, Cambridge, MA

5. Beal, W. J. 1909. Letter to L. R. Jones. American Phytopathological Society Records, Department of Special Collections. The Parks Library. Iowa State University, Ames, IA

6. Campbell, C. L., Peterson, P. D., and Griffith, C. S. 1999. The Formative
Years of Plant Pathology in the United States. American Phytopathological Society, St. Paul, MN.

7. Fitzpatrick, H. M. 1937. Historical background of the Mycological Society of America. Mycologia 29:1-25.

8. Fitzpatrick, H. M. 1983. Records and reminiscences in this anniversary year. Cornell Plant Pathol. Newsl. 28:24-26.

9. Galloway, B. T. 1928. Plant Pathology: A review of the development of the science in the United States. Agric. Hist. 2:49-60.

10. Griffith, C. S., Peterson, P. D., and Campbell, C. L. 1994. The origins of plant disease research in the United States Department of Agriculture. Plant Dis. 78:318-321.

11. Jones, L. R. 1908. Letter to C. L. Shear. American Phytopathological Society Records, Department of Special Collections. The Parks Library. Iowa State University, Ames, IA.

12. Jones, L. R. 1909. Handwritten notes on C. L. Shear. American Phytopathological Society Records, Department of Special Collections. The Parks Library. Iowa State University, Ames, IA.

13. Jones, L. R. 1909. Letter to C. L. Shear. American Phytopathological Society Records, Department of Special Collections. The Parks Library. Iowa State University, Ames, IA.

14. Jones, L. R. 1909. Letter to W. J. Beal. American Phytopathological Society Records, Department of Special Collections. The Parks Library. Iowa State University, Ames, IA.

15. Jones, L. R. 1919. Our journal, Phytopathology. Phytopathology 9:159164.

16. Kelman, A., and Peterson, P. D. 2002. Contributions of plant scientists to the development of the germ theory of disease. Microbes Infect. 4:257260.

17. McCallan, S. E. A. 1959. The American Phytopathological Society - the first fifty years. Pages 24-31 in: Plant Pathology: Problems and Progress, 1908-1958. C. S. Holton, G. W. Fischer, R. W. Fulton, H. Hart, and S. E. A. McCallan, eds. University of Wisconsin Press, Madison, WI.

18. Peterson, P. D., and Griffith, C. S. 2000. C. L. Shear: Gifted mycologist, plant pathologist, and APS founder. Annu. Rev. Phytopathol. 38:19-29.

19. Peterson, P. D., Griffith, C. S., and Campbell, C. L. 2000. Hermann von Schrenk and the rise of forest pathology in the United States. Plant Dis. 84:586-591.

20. Peterson, P. D., Jr., Griffith, C. S., and Campbell, C. L. 1996. Frank Lamson-Scribner and American plant pathology, 1885-1888. Agric. Hist. 70:33-56.

21. Rodgers, A. D. 1949. Liberty Hyde Bailey: A Story of American Plant Sciences. Princeton University Press, Princeton, NJ.

22. Shear, C. L. 1906. Societies and academies. The American Mycological Society. Science 23:186

23. Shear, C. L. 1908. Memo from Bureau of Plant Industry to all workers in Plant Pathology, December 15. American Phytopathological Society Records, Department of Special Collections. The Parks Library. Iowa State University, Ames, IA.

24. Shear, C. L. 1909. Letter to George F. Atkinson, October 25. George F. Atkinson Papers, 1880-1918. Division of Rare \& Manuscript Collections, Carl A. Kroch Library, Cornell University, Ithaca, NY.

25. Shear, C. L. 1909. Letter to L. R. Jones, April 27. American Phytopathological Society Records, Department of Special Collections. The Parks Library. Iowa State University, Ames, IA.

26. Shear, C. L. 1909. Letter to L. R. Jones, February 23. American Phytopathological Society Records, Department of Special Collections. The Parks Library. Iowa State University, Ames, IA.

27. Shear, C. L. 1910. The American Phytopathological Society. Part I. Science 31:746-757.

28. Shear, C. L. 1910. The American Phytopathological Society. Part II Science 31:790-799

29. Shear, C. L. 1919. First decade of the American Phytopathological Society. Phytopathology 9:165-170.

30. Shear, C. L., Reddick, D., and Orton, W. A. 1908. Letter to F. Hedges, December 16. American Phytopathological Society Records, Department of Special Collections. The Parks Library. Iowa State University, Ames, IA.

31. Smith, E. F. 1898. The first annual meeting of the Society for Plant Morphology and Physiology. Am. Nat. 32:96-110.

32. Smocovitis, V. B. 2006. One hundred years of American botany: A short history of the Botanical Society of America. Am. J. Bot. 93:1-12.

33. Stover, W. G. 1925. Augustine Dawson Selby, 1859-1924. Phytopathology 15:1-10.

34. Walker, J. C. 1979. Leaders in plant pathology: L. R. Jones. Annu. Rev. Phytopathol. 17:13-20.

35. Whetzel, H. H. 1908. Letter to C. L. Shear, December 19. American Phytopathological Society Records, Department of Special Collections. The Parks Library. Iowa State University, Ames, IA. 